IRA-International Journal of Management \& Social Sciences

ISSN 2455-2267; Vol.04, Issue 02 (2016)

Pg. no. 376-386

Institute of Research Advances

http://research-advances.org/index.php/RAJMSS

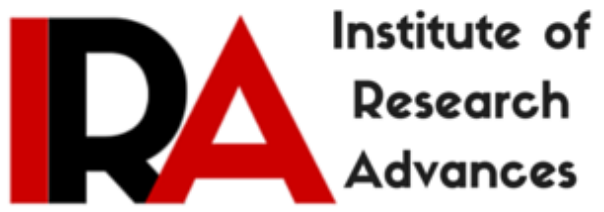

\title{
Impact of WhatsApp on youth: A Sociological Study
}

${ }^{1}$ Ms. Anshu Bhatt

Faculty, Department of Sociology,

Dr. B. R. Ambedkar University, Agra, India.

\section{${ }^{2}$ Dr. Mohd. Arshad}

Associate Professor \& Head, Department of Sociology,

Dr. B. R. Ambedkar University, Agra, India.

Type of Review: Peer Review

DOI: http://dx.doi.org/10.21013/jmss.v4.n2.p7

\section{How to cite this paper:}

Bhatt, A., \& Arshad, M. (2016). Impact of WhatsApp on youth: A Sociological Study. IRA-International Journal of Management \& Social Sciences (ISSN 2455-2267), 4(2), 376-386. doi:http://dx.doi.org/10.21013/jmss.v4.n2.p7

(C) Institute of Research Advances

(c) BY-NC

This work is licensed under a Creative Commons Attribution-Non Commercial 4.0 International License subject to proper citation to the publication source of the work.

Disclaimer: The scholarly papers as reviewed and published by the Institute of Research Advances (IRA) are the views and opinions of their respective authors and are not the views or opinions of the IRA. The IRA disclaims of any harm or loss caused due to the published content to any party. 


\section{ABSTRACT}

Today in rapidly moving world, we can see change in every moment. Therefore life is getting complicated in every phase but the technology has made life very convenient. It is evolving in the world at very fast pace and affecting people from various ways. And Whatsapp is one of the medium of such technology. Now-a-days it is becoming a popular word among youth, which is currently available in the various electronic items such as I-Phone, Android, windows phone and computer also.

Whatsapp is an amazing application, and with the help of it we can connect ourselves to the society and the whole world. It is an effective medium for the flow of information and ideas. This application is advantageous for us from many ways which occupies a major part of our day-to-day life. However, this app has emerged as an important medium for social networking and sharing of information and ideas, even it has some harmful effect on the life of youth. Hence, it is essential to know how it is affecting the life of youth and the society at large. The present study is an attempt to study the impact of Whatsapp, with reference to youth of Agra, India. This empirical study has been conducted upon 100 respondents and an Interview schedule was used as tool of data collection.

The study will reveal that whatsapp is a medium of making communication easier and faster thereby by enhancing effective flow of information, idea sharing and connecting people easier. Examining it empirically, it is found that whatsapp has also a profound negative impact on youth and adversely affects their education, behavior and routine lives. It messes up much of study time of students and spoils their spelling skills and grammatical construction of sentences. This app has been found to be highly addictive, which leaves a trace that becomes difficult to control. The impact is so powerful that users give up their real world interest their entire emotional quotient is restricted to the app. Their happiness or sadness depends on the reply which they receive from other users. They cannot control themselves from constantly chatting, replying and sharing of ideas.

\section{$\underline{\text { Introduction }}$}

Since more than 20 years ago, the creation of SMS or short message service has revolutionized the way of communicate. In 2011, 7.8 trillion SMS message were sent globally1, highlighting that SMS is a mass communication medium used by billion of people around the globe. In recent times, however, a new wave of mobile communication services called mobile instant messaging (MIM) applications have gained considerable momentum. Applications like Whatsapp, Viber and Line allow mobile users to send realtime text messages to individuals or group of friends at one time and at no cost.

Today, one of the most interesting MIM Application on the market is Whatsapp2. Whatsapp is a platform of instant messaging application across the world for Smartphone. It enables users to send and receive the location, information, Images, video, audio and text messages in real time to individuals and group of friends at no cost.

1.Mobile messaging futures 2012-2016, htt://bit.ly/QTVBQJ

2.Whatsapp,http://www.whatsapp.com/

At present, Whatsapp handles more than 10 billion messages per day3.It is easy to use; simply enter the mobile number in the device into this app. Then search all the contacts (with your permission) on the phone to figure out who else has the app already installed User can invite more contact or go ahead. Whatsapp messenger was purposely created by Brain Acton (2009) to make communication and the Distribution of multimedia messaging more easily and faster. There are thousands of social networks and 
applications available worldwide but the popularity of social network is determined by how well it meets the user's personal need and desire. This kind of platform was designed as a way of communication for friends, family and strangers to have discussion and interaction. It helps the people to explore new opportunities and experiences. Social networking allows youth to express them by uploading their profiles that highlight their talent and experience of life. A social networking can be affected by cost, time, culture, geography and many other features in which Whatsapp is one of the most popular application which emerges like the culture of MacDonald that create a new taste in social networking market and majority of youth crazy for this. It enables users to have multimedia downloads text messaging without having to pay short messages service (SMS). This is the feature that makes Whatsapp quite popular among youth. With the help of this application, an Individual can chat with family, friends beyond the limit of seas and creates familiar environment for it. It also helps to keep contact to everybody at one time. No doubt, this amazing app is useful for us from many ways. One instance can be given in respect of this; we are buying something and have confusion about the item. Then to remove confusion we can take the picture of this and send it to our dear one on Whatsaap to get suggestion.

3.Whatsapp hits new record with 10 billion total message in one day http://tnw.co/Txjbqa

We can find more other advantages, if we will keenly observe the life of youth. They are increasingly utilizing this application for personal update, event activities, notes and messages. But apart from this, it occupies our lives from all around and makes us addict of it which is difficult to control.

Thus, through this paper, we try to focus on the positive as well as negative impact of Whatsapp on youth and discuss which aspect of life affects them strongly, positive or negative.

\section{$\underline{\text { Review of literature }}$}

Whatsaap is an application of social media therefore literary review of this paper can also be covered herewith.

Cox\&Rethman(2011) Social media can be defined as forms of electronic communication through which user can interact among people freely and can share, exchange and discuss the Information, ideas, personal message and other content between each-other such as using a multimedia messages, personal words, pictures, video and audio, and utilizes online platform only by connecting to the Internet.

\section{Dr.Neelamalar\&P.Chitra,AnnaUniversity(2009)}

They conducted a study to identify the issues regarding the youth's social networking usage and the resultant impact on their social interactions. The sample size was 100 [50 teens 17-19yrs and 50 youths 20-22yrs]. The findings of the study include $98 \%$ number of people who are the members in social networking sites in which $68 \%$ are strangers, $7 \%$ are those who have very intimate relationship with their online friends (strangers) and 20\% are good friends with the virtual strangers. Thus it is a positive indication that Indian youth are not only techno-savvy and socially active, but they also possess social consciousness.

Johnson Yeboah \&Georg Dominic Ewur Takoradi Polytechnic,Ghana (2014)conducted a research to find out the Impact of whatsapp (application of social networking) messenger on academic performance of youth and data was collected from 550 students of territory institutions of Ghana. The result indicates that whatsapp has negative impact on the study of youth. It engendered procrastination related problem, error of spellings and grammatical construction of sentences. Therefore it is difficult to balance simultaneously the online activities and academic performance with whatsaap. 


\section{Dr. Avni Maniar and Ms. Annal Modi university of Baroda, Gujarat (2013)}

A mini research was conducted on 30 collage going students of Baroda. The findings of this study revealed that high majority of them possess smart phones and Giga byte Internet plan. All of them used Whatsapp for chatting with their contacts. They also used this application for sharing audio and video files. The purpose behind using this app was keeping connectivity between their friends and relatives. Hence, this application is popular amongst in users.

Karen church and Rodrigo de Oliveira, Munich German (2013) were conducted telephonic research to explore those factors which influence the acceptance, usage and growing popularity of such MIM application rather than SMS. For this research, various countries are involved including Finland, Norway, Japan, UK and the USA and the finding of the research shows significant impacts of this upon the people of these countries and the reasons for migration to such MIM applications. The nature and intent of WhatsApp messages tend to be more social, informal and conversational in nature. While SMS is seen more privacy preserving, more formal and generally more reliable evidence that shows that no technology is a substitute for this.

Baran (2010) Study shows that social networking sites are quite appropriate for the harmony of the teachers and students. Such tool can allow them to share knowledge in formal education context.

Tsai and Lin (2012) suggest that Internet addiction is an important concern among adolescents. In their study of 700 Taiwanese high school students, 88 were deemed Internet addicts according to the Internet Addiction Scale which conducted for high school students in Taiwan (IAST). Current research indicates that ego-identity achievement in middle school students is negatively related to pathological and extreme Internet use. This research says that these students are getting addicted to internet which is the serious problem for the adolescents in present age.

\section{Objectives;}

- The preliminary aim of the study is to examine the intensity of the usage of Whatsapp messenger among the youth of Agra region.

- The major objective of this paper is to investigate the way, how it affects the education, psychology, routine life, family life and expenditure of the youth.

- The other objective of this paper is to evaluate the degree of positive and negative impact of Whatsapp messenger among youth.

\section{Hypothesis;}

- The Intensity of usage of Whatsapp messenger is very high among youth because of its cheap cost.

- Whatsapp messenger has negative impact on youth.

\section{Methodology;}

A strong methodology is the backbone of the research. It provides the ground to the research therefore the topic should also be selective. This research deals with qualitative approach with the help of quantitative analysis to find out in depth, how does it affect the psychology, routine life and family life of youth?

The research has made the use of survey method. Survey was conducted among randomly selected Whatsapp user in Agra region with sample size of 100 people between the age group of 17 to 30 years, who were school ,college student, employee and home makers .This age group of youth(17-30years)who has chosen for the survey are the heavy users of social media and early adopters of advanced technological application. The survey was conducted through Interview schedule, which is circulated in 
school, college and work places. Some data were collected through personal interview to get a deeper insight, and more information regarding to the research. This research also involves direct observation method with the help of family members, peers, friends, colleagues who help to know some of related facts in the research.

The Sample size retains 100 of people who were randomly selected from colleges, schools and working places of Agra district.

\section{Data analysis and Interpretation}

Figure 1: Purpose to join the whatsapp
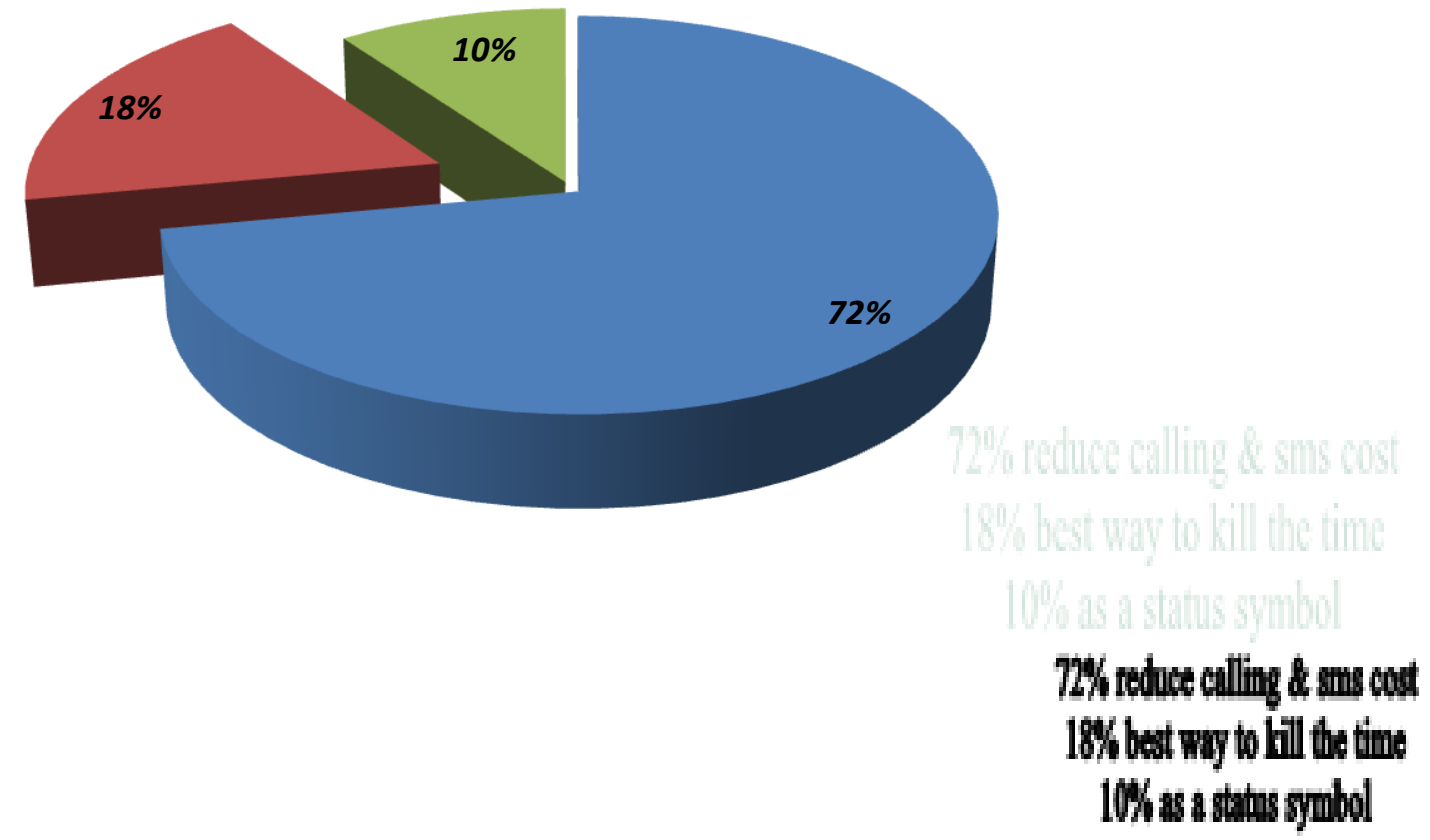

The finding of the survey reveals that the majority of youth which is $72 \%$ of the sample clearly make strong view that they use whatsapp for being in touch with family, friends, and acquaintances because of its cheap cost which reduce the calling \& sms expenditure and $18 \%$ of respondents have the opinion that it is the best way to kill the time, $10 \%$ of respondents say that they use whatsapp for their status symbol. 
Figure 2 Activity on whatsapp

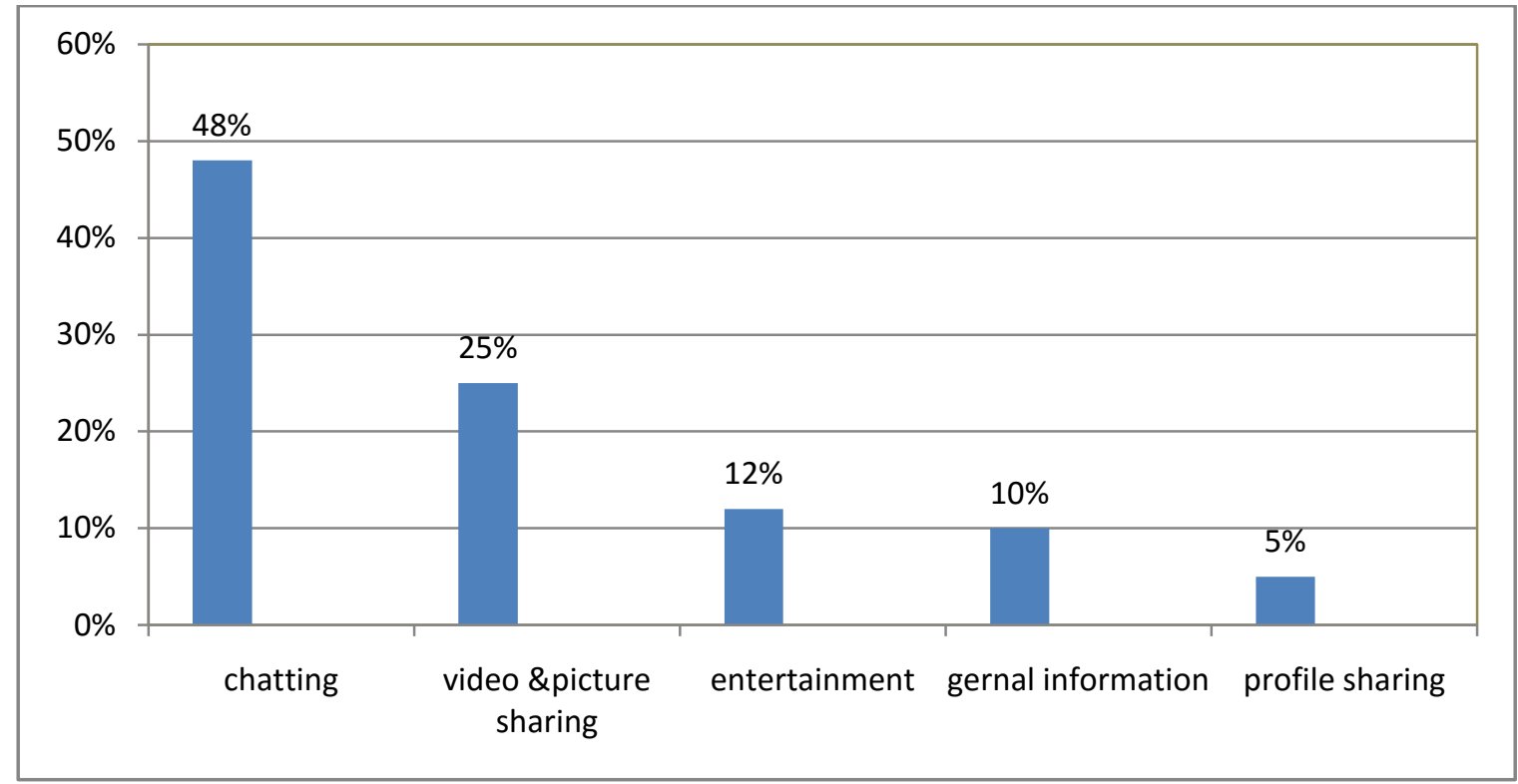

While researchers asked to the respondents what do they frequently use on whatsapp, the researchers were amazed at their responses. Because the majority of them about $48 \%$ respondents give the reply that they remain engage in chatting frequently on Whatsapp rather than sharing videos or any other activity, moderate responses of about $25 \%$ respondents were to share comedy videos \& joking pictures to remove their tension, $12 \%$ of respondents take it as a tool of entertainment and gossip, $10 \%$ of respondents share general things like what are the other members doing and to whom they busy, and very low percentile of $5 \%$ users update their status and see the profile pictures of other on Watsapp.

Table 1 Frequency of whatsapp

\begin{tabular}{|r|r|}
\hline Respondent (\%) & Frequency in the day \\
\hline $63 \%$ & 50 times in a day \\
\hline $21 \%$ & 20 times in a day \\
\hline $16 \%$ & 100 times in a day \\
\hline
\end{tabular}

The culture of whatsaap is getting high in Agra region. $60 \%$ of the total respondents use whatsapp 50 times in a day. They check frequently their cell-phone on the every beep of whatsapp inspite of engaging in studying, eating or doing some-thing important. $21 \%$ of the respondent check their app 20 times in a day and $16 \%$ of them are prolific user because they check their app 100 times in a day. Thus, the data reveals that majority of respondents use the app 50 times, which is a remarkable fact.

Table 2: Criteria to include in whatsapp list

\begin{tabular}{|l|l|}
\hline Respondent & Responses (\%) \\
\hline Close friends & $40 \%$ \\
\hline Work colleagues & $25 \%$ \\
\hline Acquaintances & $20 \%$ \\
\hline
\end{tabular}




\begin{tabular}{|l|l|}
\hline Closely connected communities & $8 \%$ \\
\hline Strangers & $7 \%$ \\
\hline
\end{tabular}

However to better understand the effect of watsapp on youth, it is analyzed that on what basis the youth establish their virtual circle. Then $40 \%$ of the respondents stated that they include only those person in their whatsapp list on whom they have strong trust hence they choose only close friends for it to share personal talks; $25 \%$ of samples were those who invite their work colleague on whatsapp for business purpose; while $20 \%$ of the respondents revealed that they include only those person on whatsapp to whom they are well acquainted in real life. A very low percentile in this sequence, about 8 or $7 \%$ of youth choose closely connected community persons like family members and relatives or absolute stranger. Thus the study reveals that the youth on whatsapp give high priority to their personal preferences and likeness rather than other logical or rational reason.

Table 3: Impact of whatsapp on study

\begin{tabular}{|c|c|c|c|c|c|}
\hline Responses & $\begin{array}{l}\text { Occupation of } \\
\text { respondent }\end{array}$ & Positive & Negative & Yes & No \\
\hline How does whatapp affect yours studies & $\begin{array}{l}\text { Studying }(37 \%) \\
\text { Job }(32 \%) \\
\text { Both }(31 \%)\end{array}$ & $21 \%$ & $47 \%$ & & \\
\hline Do you use hinglish on whatsaap & & & & $69 \%$ & $31 \%$ \\
\hline
\end{tabular}

According to the survey, $68 \%$ of total respondents were engaged in working and studying together and out of which $47 \%$ of them stated to researcher that whatsapp takes lots of time of their study and could not be able to complete their assignment. Many times, they strive to control themselves to view whatsapp messages but they do not get satisfied until they check their app. While about 69\% of respondents admitted that they use hinglish during conversation that weakens their grammar. They used short hand in their conversation which destroys their grammatical construction of sentences. While remaining $21 \%$ of respondents (of the total $68 \%$ respondent) stated that, whatsapp affects their study positively because through this app they can connect to their faculty and classmates and get immediate responses of their quarry. They can also share notes and purposive information through it. While $31 \%$ of researchers were not agree with the view that whatsapp is responsible for destroying their spellings and grammar. 
Table 4 Impact of whatsapp on real relationship

\begin{tabular}{|l|l|l|}
\hline Responses & Agree & Disagree \\
\hline Whatsaap overtaking your real relationship & $67 \%$ & $33 \%$ \\
\hline Procrastinate work because of whatsapp & $72 \%$ & $28 \%$ \\
\hline
\end{tabular}

The above table reveals that, the vast majority of youth is about $67 \%$ says that whatsapp takes over their real relations. The reason of this is that now-a-day, most of the youth takes the well wishes from their friends, relatives and acquaintances on whatsapp only and avoid to visiting their home directly. The active users of Whatsapp check their app on per beep instead of spending time with their family. They seem to stick with their cell-phone which destroys their real relationship and reduce communication between family members. While $33 \%$ of the respondents have the positive opinion. They have the view that whatsapp does not take over their relationship because they think that it is desirable to check the app ,but you must not be addict to check again and again this app.

Further $72 \%$ of respondents stated that, they procrastinate their work due to whatsapp. It creates serious interferences with their work, studies, relationship and normal social functioning. But low percentile about $28 \%$ respondents viewed paradoxical. They have the idea that this app does not affect them in negative way because they give first preference to their real activities instead of online activities.

\section{Table 5 Psychological impact and interferences of whatsapp}

\begin{tabular}{|l|l|l|l|}
\hline Responses & Agree & Disagree & Neutral \\
\hline Have you been addict of whatsapp & $71 \%$ & $29 \%$ & \\
\hline Do you feel psychological changes in yourself because of whatsapp & $58 \%$ & $28 \%$ & $14 \%$ \\
\hline Does whatsapp occupying your privacy & $80 \%$ & $17 \%$ & $3 \%$ \\
\hline
\end{tabular}

There is a very narrow border line between favorite pass time and addiction. One starts using it in initial level to catch friends but ultimately ends up with a lot of lavish time in talking, playful quizzes. Hence majority of youth about $71 \%$ reveals this strange fact that, they deleted whatsapp many time but after some interval, they launched it again. Therefore they admit that they have become addict of this app which put an adverse impact on their mental health while remaining $29 \%$ were denied such fact.

In case of finding out the psychological impact on the users, a majority of 58\% was strongly agreed that their mood fluctuate with responses of whatsapp message. Its impact is so powerful that users leave real world interest, and even their entire emotions are depend on this app. They get happy or sad on 
the reply of the other users. They have serious addiction issue and have been hypnotized and controlled by the other users. While $28 \%$ were disagreed with this fact.

In order to find out the level of interference in the privacy of the users, $80 \%$ of the respondents, out of total number view that whatsapp occupies their privacy and personal life. But they feel helpless to control themselves from constantly chatting, replying and sharing information from all the time. It is not good to know about each and every moment of other people's personal life. For involving others in their small decisions and also forcing their ideas on other decision can be proved very dangerous and hazardous.

\section{Findings:}

1. Findings shows majority of youth about $72 \%$ joined whatsapp because it is a good source of communication and youth can be in touch with their love one through it. Apart from this it reduces expenditure also on calls and SMS.

2. The intensity of whatsapp is very high in Agra region. The youth use whatsapp 50 times in a day.

3. Moderate responses about $48 \%$ reveal that their favorite activities of on whatsapp are chatting, comedy and joking videos, and picture sharing.

4. A vast percentile of young generation about $63 \%$ visit Whatsapp 50 times in a day which is remarkable.

5. According to the survey, $40 \%$ of the sample respondents include only close friends in their whatsapp list.

6. $47 \%$ out of the $68 \%$ of studying youth strongly stated that whatsapp occupies their studying time and responsible for a lot of grammatical mistake, lack of concentration while lecturing. Thus it has negative effect on the study.

7. $57 \%$ of sample has reported that whatsapp overtakes their real relationship. Hence it is strong reason for social isolation.

8. High percentile about $67 \%$ admitted that, they have become addicted of whatsapp. Their entire emotions depend on this app, which create adverse impact on their psychology.

9. $71 \%$ show that whatsapp made a serious interferences in their privacy.

\section{Conclusion and recommendation;}

This paper investigates the impact of whatsapp on youth at Agra region; therefore this study reveals considerable facts regarding youth and whatsapp. However whatsapp is much quicker and more convenient way to interact with people which enhance the effective flow of massages and ideas among youth. Indeed intensity of whatsapp is very high among youth because it reduces calling and SMS costs. Therefore its primary objective and hypothesis evidently accepted.

The main goal of this paper is to find out impact of whatsapp on youth. Whatsapp is beneficial from many ways like to keep in touch from their dear ones, especially when they live far from their home. It is very helpful even for those people who feel shyness in social interaction. The most useful source of it is to share their thoughts easily. It is also a boom for those who are disable and unable to go to the others homes. But through it, they can deal with world.

As every invention has its pros and cons in its own sense, similarly whatsapp has also, the greater drawback for its highly addictive nature. There is a very narrow line between the favorite pass time and the addiction of Whatsapp on youth. They delete whatsapp but after couple of days, they again launch it. It is the major reason for having negative impact on youth's psychology. Most of the time, youth seems stick with their cell-phones for knowing each and every moment of other person's personal life. They also involve others in their small decisions or forcing their ideas on other decision which can be proved dangerous and hazardous for personal liberty. 
Thus, the result shows that whatsapp is a major cause for social isolation because of avoiding to visit in the house of their acquaintances and promote only virtual relationship instead of real relationship. It creates interferences in daily routine and privacy of the youth. It also has the negative impact on the study of the youth. It encourages the grammatical mistakes, error in sentence constriction, lectures bunking. It annihilates lavish time of career building of youth. Therefore whatapp is like a sharp knife if you do not know the way of using it, you can cut yourself. Hence youth must be careful while using whatsapp.

\section{Recommendation;}

First, time management is essential for online activities.

People should give the priority of their life. They should do not think, that whatsapp is a priority.

Telecommunication companies should reduce their calling and SMS rates thereby for reducing the usage of whatsapp.

People should try to access whatsapp through Wi-Fi but do not use it every time. For it the connectivity can be available on college. Then it will helpful to reduce addiction.

Cell-phones should be forbidden in lecture hall

\section{References;}

1. Neelamalar, M., \& Chitra, P. (2009). New media and society. Education and communication, [cited 2009 Dec 9]; 6(1), 125-45. Available from: URL: http://www.ecn.edu; Retrieved on Octuber8th, 2014.

2. William L, Wilkin. (2009). Negative impacts of internet use. Curr opin psychiatry, 22(4), 351-6. [cited 2010 Apr 23]; Retrieved $7^{\text {th }}$ January 2014 from: URL: http://www.medscape.com

3. Lavalekar, A. (2009). Social awareness in relation to media among high school students. Psychological studies [cited 2010 May 23]; 45(3), 178-80, Available from: URL: http://www.nipccd.nic.in Retrieved on $4^{\text {th }}$ February, 2015

4. Yusuf, M,O, \& Afolabi, A.O. (2010). Effects of CAT on secondary school students performance. Turkish journal of educational technology. [2010 Jan 23]; 9(1), 63-9. Available from: http://www.tojet.net; Retrieved on $2^{\text {nd }}$ January, 2015.

5. Yeboah Johanson\&Ewur Dominic George(2014).The impact of whatsapp messenger usage on students performance .journal of education and practice .vol 4 no 62014.

6. Dr.maniar Avani\& Ms Modi Anal(2013)Whatsapp and youth, EXCEL International Journal of Multidisciplinary Management Studies,vol 32013.

7. Church Karen\&Oliveira de Rodrigo, What's app with whatsapp? comparing mobile instant messaging behaviors with traditional sms,mobile $\mathrm{HcI}(2013)$ collaboration and communication .p.g,352to 361

8. Ito, M. Mobile phones, japanese youth, and there-placement of social contact. Mobil Communications(2005), 131-148.

9. Ghanem, R. (2012, September 24). Social media connecting people. Saudi Gazette. Retrieved from

http://www.saudigazette.com.sa/index.cfm?method=home.regcon\&contentid=20120924137282

9 Beer, David. (2008). Social network(ing) sites...revisiting the story so far: A response to Danah Boyd \&Nicole Ellison. Journal of Computer-Mediated Communication, 13 (2), 516-529

10. Lavalekar, A. (2009). Social awareness in relation to media among high school students. Psychological studies [cited 2010 May 23]; 45(3), 178-80, Available from: URL: http://www.nipccd.nic.in Retrieved on $4^{\text {th }}$ February, 2015.

11. Donath, B. (2011). The communication systems integrating social network ties. Perspectives online, [cited 2011 Jan 7]; 1(2), 10-5, Retrieved October 5 ${ }^{\text {th }}, 2014$ from: http://www.seer.perspectivasonline.com 
12. Ranade, M.D. (2008). Science teaching through computer assisted instruction. Research findings and insights. [cited 2009 Aug 29]; 17(1), Available from: URL: http://www.hbcse.res.in; Retrieved January $21^{\text {st }}, 2015$.

13. .Hinduja S.,Patchin J(2007); offline consequences of online Victimization: Schooly Violence and delinquency :journal of S.violence.2007:6(3)89-112 